\title{
Discovery and multi-analytical study of the last missing quarter from René Magritte's La pose enchantée
}

\author{
Catherine Defeyt $^{1 *}\left(\mathbb{D}\right.$, Elodie Herens ${ }^{1}$, Frederik Leen ${ }^{2}$, Francisca Vandepitte ${ }^{2}$ and David Strivay ${ }^{1}$
}

\begin{abstract}
The last missing quarter of La pose enchantée, a 1927 Magritte's oil painting disappeared in 1932, has been finally found beneath Dieu n'est pas un saint, picture painted by the Belgian surrealist between 1935 and 1936, conserved at the Brussels Magritte Museum (Royal Museums of Fine Arts of Belgium) (inv. 11681). The in-depth study conducted on Dieu n'est pas un saint by means of non-invasive and complementary imaging and analytical techniques has allowed formulating substantiated conclusions regarding this double painting. On the one hand, the routine imaging methods, including XRR, IRR and digital microscopy, have delivered a comprehensive outcome regarding the transformation process of the right top part of La pose enchantée into the current composition. On the other hand, the pigments used for both the visible and the hidden composition have been characterized through the MA-XRF analysis of the whole picture and punctual Raman measurements. Additionally, the present paper proposes a virtual colorization of La pose enchantée, which has been build on the basis of the overall material evidences collected about the right top part lying beneath Dieu n'est pas un saint.
\end{abstract}

Keywords: René Magritte, Hidden painting, MA-XRF, Pigments, Non-invasive imaging techniques

\section{Introduction}

The most famous Belgian surrealist artist, René Magritte (1898-1967), was always reluctant to talk about the painting materials and techniques he used, and, although abundant, the literature devoted to Magritte deals primarily with stylistic, iconographic and psychoanalytic approaches [1-5].

As a result, the materiality of his work is poorly documented and, so far remains understudied. Yet it is by nature a fundamental aspect of Magritte's work that conditions the preservation and the transmission of his cultural heritage legacy. In such circumstances, questioning the painting materiality appears as the only possible way of moving forward. The research project Magritte on practice has been created in response to the lack of available information on Magritte's painting materials

\footnotetext{
*Correspondence: Catherine.defeyt@ulg.ac.be

${ }^{1}$ Centre Européen d'Archéométrie, UR Art, Archéologie, Patrimoine, University of Liège, Allée du 6 Août 10, Sart Tilman B15, 4000 Liege, Belgium

Full list of author information is available at the end of the article
}

and techniques. This on-going research project, initiated in 2016, is a collaboration of the Royal Museums of Fine Arts of Belgium (MRBAB/KMSKB) and the Centre Européen d'Archéométrie of the University of Liège (CEA), which aims to throw a new light on the René Magritte's painted oeuvre by applying technical art history and conservation science tools on an extended number of paintings he made throughout his career. For this purpose, 42 oil paintings and 21 gouaches made between 1921 and 1963, conserved at the Magritte Museum, are being investigated in situ by means of non-invasive and complementary scientific imaging and analytical methods.

The in-depth study of a large panel of Magritte's paintings through scientific tools addresses multiple issues; one of them is the discovery of lost youth compositions. Indeed, the precarious financial situation of the painter between 1920 and 1935 had led him to regularly reuse canvases from his former compositions. Regarding this Magritte's habit and the extended corpus of works intended to be investigated, one could reasonably expect to discover underlying painted compositions, 
unpublished or indexed in the René Magritte Catalogue Raisonné (RMCR) with the mention "whereabouts unknown".

It is precisely in the frame of Magritte on practice that the last quarter of La pose enchantée has recently been unveiled, amongst the oil paintings from the Magritte museum collection.

La pose enchantée (RMCR $\mathrm{n}^{\circ} 163$ ) is a major Magritte's large-scale oil painting made in 1927 that has disappeared since 1932 [6]. It has first resurfaced in 2013 through the discovery of its upper and lower left parts, in the subsurface of two oil paintings from 1935, respectively Le portrait (RMCR $\mathrm{n}^{\circ} 379$ ) and Le modèle rouge ( $\mathrm{RMCR} \mathrm{n}^{\circ} 382$ ) [7, 8]. In 2016, it is the lower right section of La pose enchantée that was discovered beneath the paint layers of La condition humaine, dating also from 1935 (RMCR $n^{\circ} 390$ ) [9]. Until very recently, what happened to the upper right section of this quartered painting remained a challenging question addressed to art historians and conservation scientists around the world. The last missing quarter is now located on the subsurface of Dieu n'est pas un saint, painted by Magritte in 1935-36 (RMCR n³92),

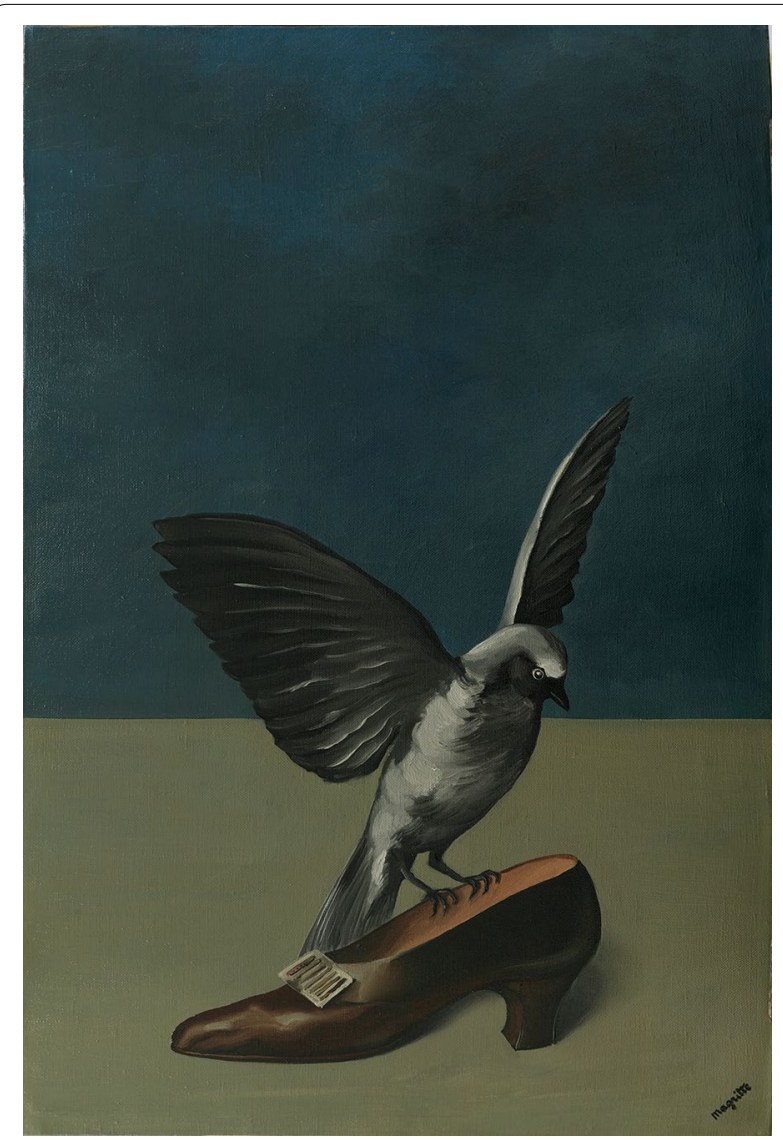

Fig. 1 René Magritte, Dieu n'est pas un saint, 1935-36, oil on canvas, $67.2 \times 43$ cm, MRBAB/KMSKB, Brussels, inv. 11681. @Ch. Herscovici, Belgium shown in Fig. 1. The present paper proposes an overview of the technical and material information collected about this double picture, by combining X-ray Radiography (XRR), infra-red reflectography (IRR), X-ray fluorescence (XRF), Raman spectroscopy (RS), high-resolution photography under visible and ultra-violet (UV) light, and digital microscopy techniques.

\section{Experimental}

A high-resolution photographic documentation was first gathered. It incorporates full size images of Dieu n'est pas un saint under visible (Fig. 1) and UV light (Additional file 1: Figure S1), acquired by using the homemade scanning system of the CEA [10]. The acquired images have been enriched by XRR and IRR images (Fig. 2). The painting surface was also examined with a Dino-Lite digital microscope ${ }^{\mathrm{TM}}$.

In order to obtain further details on the hidden composition and to get a better understanding of the pigments distribution through elemental maps, XRF spectroscopy was used in macro scanning mode (MA-XRF). The XRF scan of the whole painting has been completed in approximately $35 \mathrm{~h}$ by using the CEA translation stage and homemade XRF system [11-13], made of a Moxtek ${ }^{\text {TM }}$ Magnum X-ray tube $(50 \mathrm{kV})$ (with a $\mathrm{Ag}$ anode), a detector X-123SDD Amptek ${ }^{\mathrm{TM}}\left(25 \mathrm{~mm}^{2}\right)$, with a resolution of 130 at $5.9 \mathrm{keV}$. Scanning step was set to $1 \mathrm{~mm}$, speed to $3 \mathrm{~mm} / \mathrm{s}$. X-ray tube was set to a voltage of $40 \mathrm{kV}$ and a current of $120 \mu \mathrm{A}$. Spectra were treated in batch mode using PyMCA [14], allowing to separate the signals from the different chemical elements.

The analyses by RS were performed with the Enwave Optronics setup (portable Raman analyzer I-Dual-G), using a laser at $785 \mathrm{~nm}$ [15]. Three Raman spectra of $10 \mathrm{~s}$ integrated three times were acquired for each of the twelve investigated sites, with the lowest laser power necessary to obtain valuable results (ca. $30 \mathrm{~mW}$ ). The recorded spectra were treated using GRAMS $\mathrm{AI}^{\mathrm{TM}}$. The MA-XRF analysis and the RS measurements were performed at the MRBAB/KMSKB thanks to the CEA portable instrumentation.

\section{Results and discussion}

A preliminary visual examination of the painting without frame pointed out the presence of painted canvas edges alongside the stretcher. The blue and ochre colors of the current background are actually extended over the tacking edges. The XRR image recorded for Dieu n'est pas un saint, illustrated in Fig. 2, unveiled straightaway a female nude from above the head to the lower breast, unrelated to the current composition. Portrayed in profile, in a sculptural style, the truncated large-scale female figure beneath the surface paint layers was promptly 


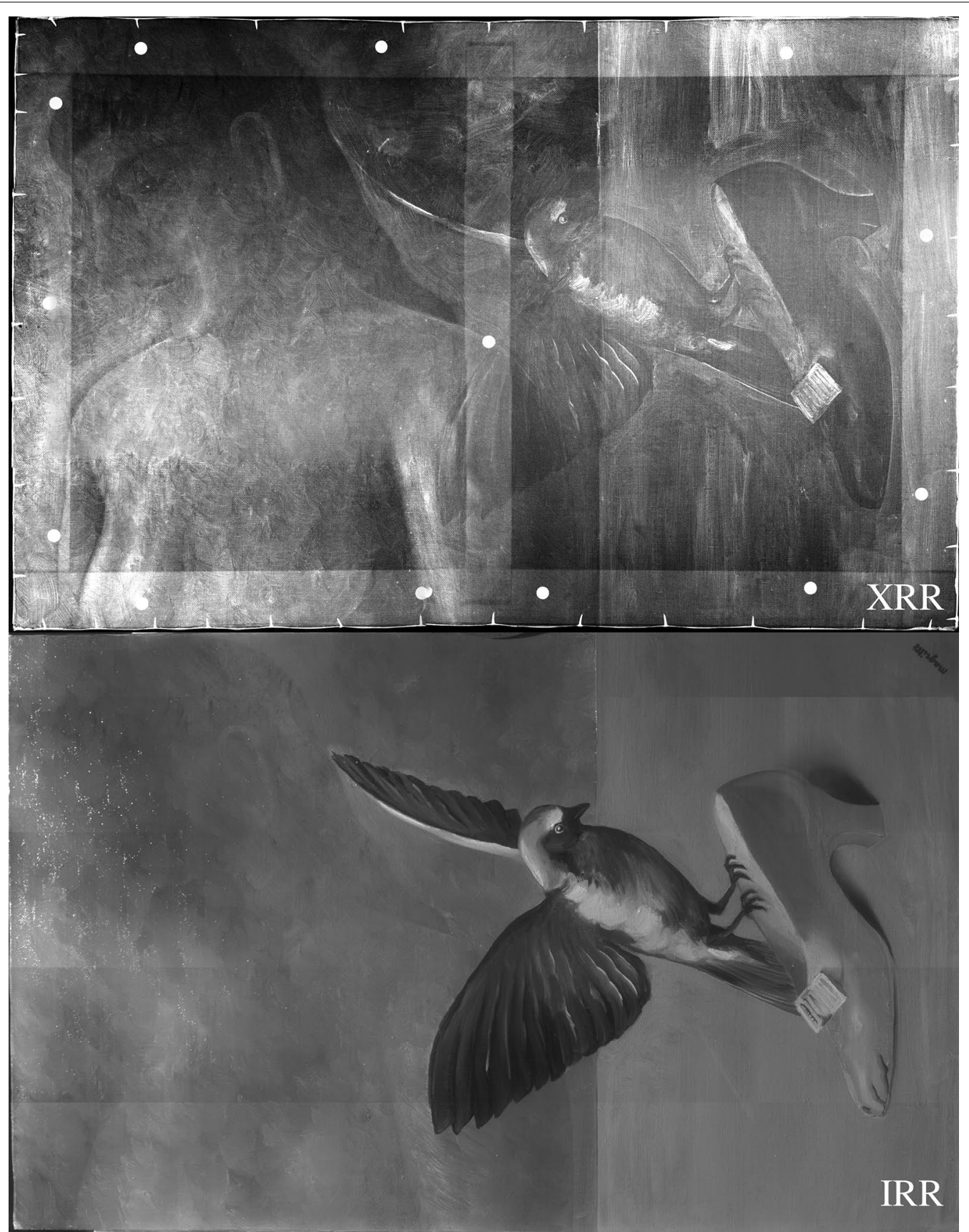

Fig. 2 XRR and IRR of Dieu n'est pas un saint, in landscape orientation, revealing a truncated female nude (from above the head to the lower breast) beneath the current picture

identified as being the last missing quarter of La pose enchantée (RMCR n ${ }^{\circ} 163$ ), presented in Fig. 3. Executed by Magritte in 1927, this large-format oil painting had disappeared since more than 80 years. The painting was shown the same year in October at the Galérie Epoque, Brussels. The last trace of La pose enchantée is found in a letter dated 3th November 1932 from the secretary of the Oeuvre Nationale des Beaux-Arts asking Magritte to remove the painting that has been submitted for the Salon held in the Palais des Beaux-Arts, Brussels (See: RMCR $n^{\circ}$ 163). Between 2013 and 2016, the top left side and the lower left and right parts of the lost composition have been located underneath three distinct oil paintings from 1935, respectively titled Le portrait (RMCR 


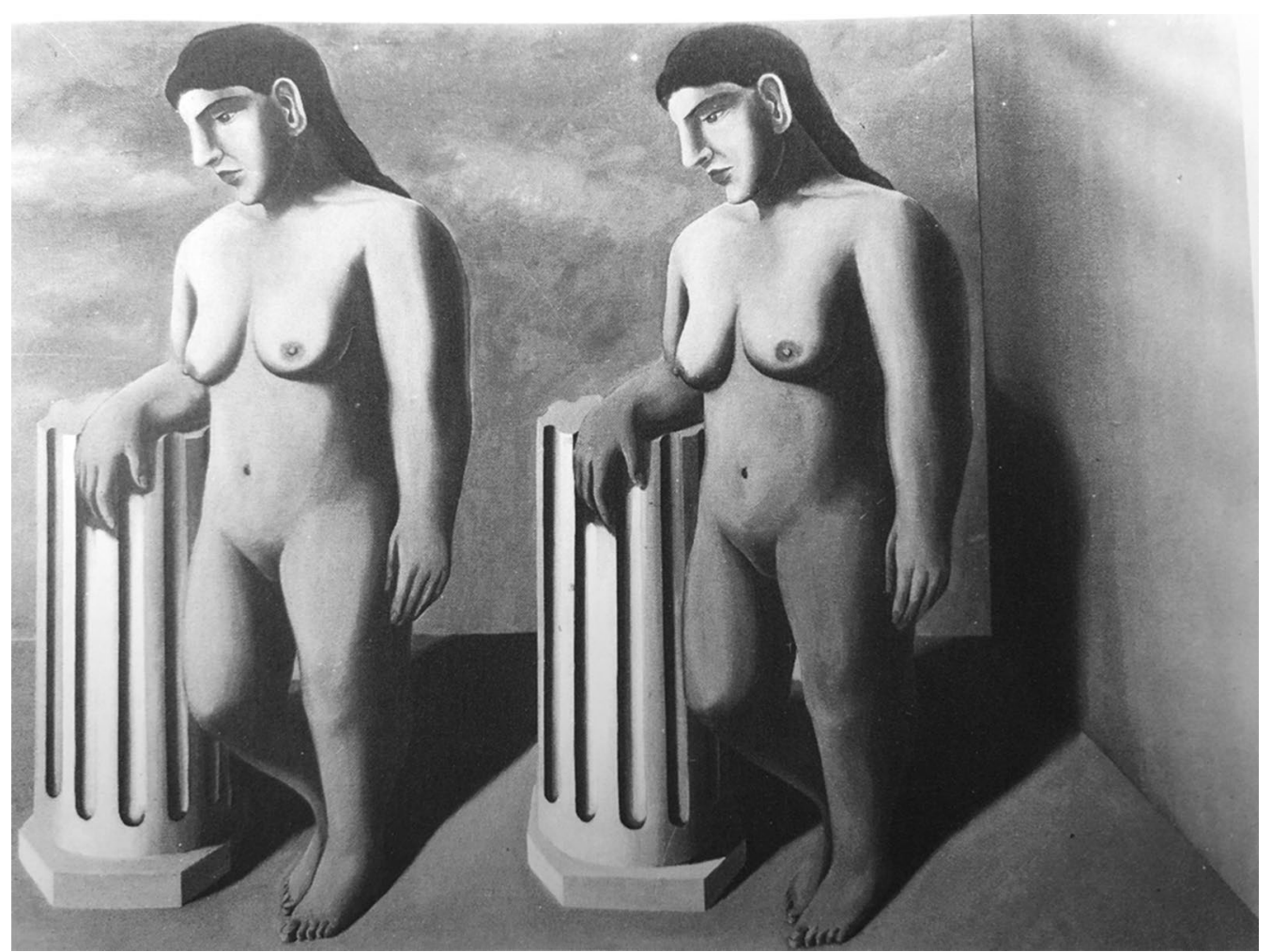

Fig. 3 René Magritte, La pose enchantée, 1927, oil on canvas, listed under n¹63 in the RMCR with the mention "whereabouts unknown". Black and white photograph reproduced in RMCR. $\odot$ Ch. Herscovici, Belgium

$\mathrm{n}^{\circ} 379$ ), Le modèle rouge ( $\mathrm{RMCR} \mathrm{n}^{\circ} 382$ ) and La condition humaine (RMCR $\left.\mathrm{n}^{\circ} 390\right)[8,9]$. The discovery of the top right part of La pose enchantée beneath Dieu n'est pas un saint (RMCR $\mathrm{n}^{\circ} 392$ ) finally allows resolving the worldwide puzzle caused by this important Magritte's youth painting, untraceable from 1932 [6]. Note that the last discovered quarter differ from the other parts through its smaller format $(67.2 \times 43 \mathrm{~cm})$. The Fig. 4 shows the four X-ray radiographs unveiling the four parts of La pose enchantée, superposed on the black and white photograph of the lost composition (reproduced in the RMCR). By comparing the XRR and the picture currently visible (Figs. 1 and 2), one can see the skyline dividing the top blue and the lower ochre backgrounds perfectly superposes the borderline between the sky and the wall from the underlying composition. While the sky area (including the nude) has been transformed into a uniform blue background, the wall has been changed into an even ochre background. Here, it is interesting to note that Magritte used the blue and ochre colored surfaces exactly in the opposite way for transforming the upper left side of the quartered painting into Le portrait. Besides the routine imaging techniques, the MA-XRF analysis conducted on the whole picture has provided further substantial information about the hidden picture, especially in regards to the palette used for it. Indeed, the elemental distribution maps recorded for Dieu n'est pas un saint allowed characterizing the inorganic pigments associated to the features formerly depicted. For the sake of clarity, the material information and the analytical data collected for the ground layer, the female figure, the sky/ blue background, the wall/ocher background, the dove and the shoe, are discussed separately.

\section{Ground layer}

The ground layer is no longer accessible on the canvas edges. Although it remains difficult to conclude anything without cross-section to investigate, the higher intensity of the $\mathrm{Zn}$ and the $\mathrm{Ca}$ signals detected in the whitish thin linear cracks, along the length of the stretcher edges, is compliant with a zinc white rich priming layer rich, involving a calcium-based extender, such as chalk and gypsum.

\section{Female figure}

On the basis of the MA-XRF PbL, Fe and Zn maps shown in Fig. 5, the flesh tones of the female figure primarily involve lead white, zinc white and iron based pigment(s). 


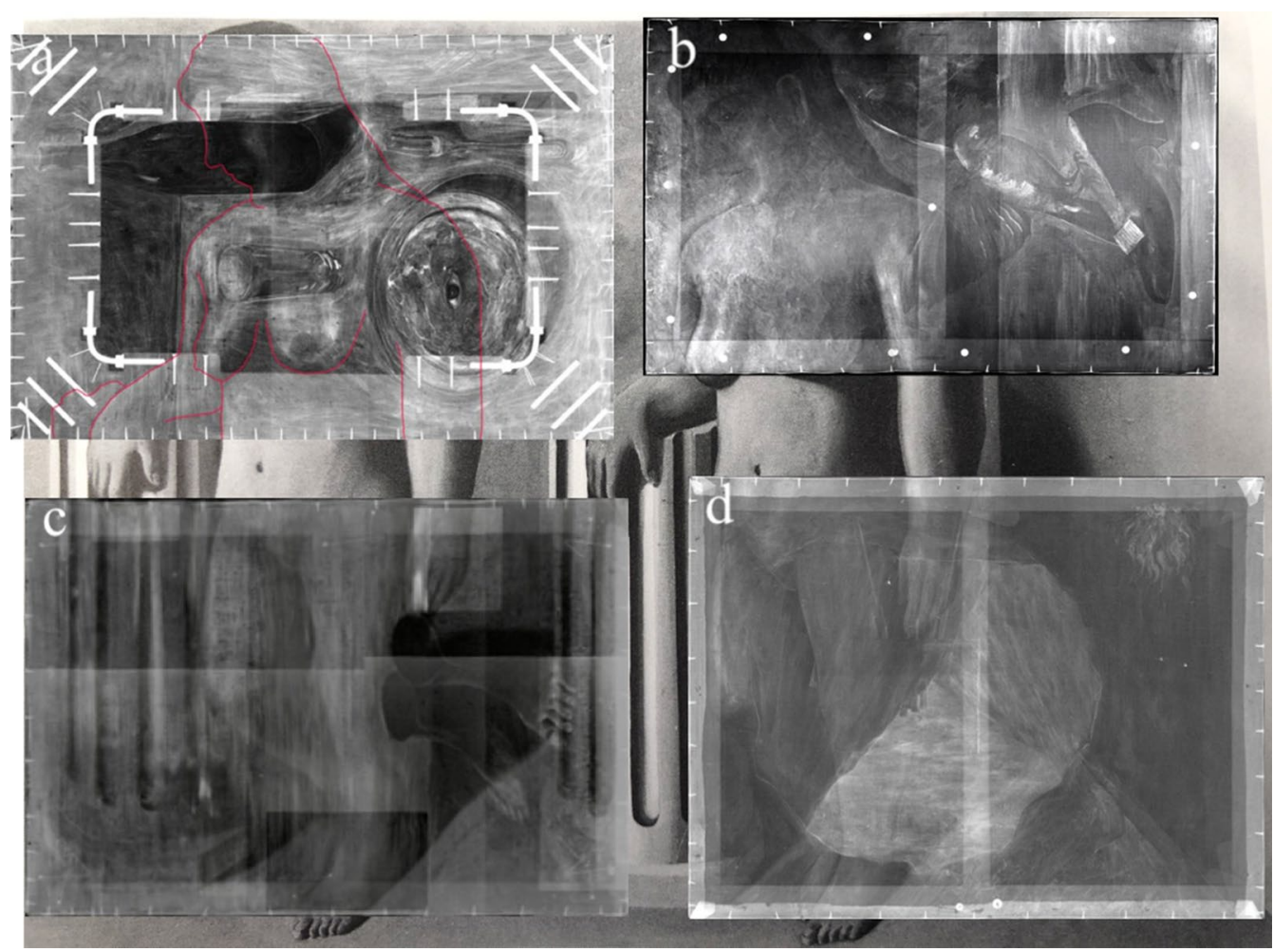

Fig. 4 X-ray radiographs unveiling the four parts of La pose enchantée superposed on the painting illustration taken from the RMCR. a Le portrait, 1935, oil on canvas, $73.3 \times 50.2 \mathrm{~cm}$, MoMA, New York [7, 8], b Dieu n'est pas un saint, 1935-36, Oil on canvas, $67.2 \times 43 \mathrm{~cm}$, MRBAB/KMSKB, Brussels, c Le modèle rouge, 1935, Oil on canvas, $72 \times 48.5 \mathrm{~cm}$, Moderna Museet, Stockholm [7, 8], d La condition humaine, Oil on canvas, $54.2 \times 73.2 \mathrm{~cm}$, Norwich Castle, United Kingdom [9]. @Ch. Herscovici, Belgium

By comparing the XRR and the PbL map, one can see that the features appearing brighter in the radiograph correspond to lead rich areas. The $\mathrm{Zn}$ scan image outlines some areas richer in zinc white, such as the face and the region between the left breast and the left arm, and appears as the negative image of the PbL distribution map. The MA-XRF scan of mercury shows isolated Vermilion-based highlights over the lips, the nose and the ear of the nude. The obtained Hg distribution map is fully consistent with the results obtained for the left female figure lying beneath Le portrait [8]. The distribution of the Fe signals detected in the nude indicates the use of one or more ferrous pigment(s) for the flesh tones rendering. The presence of Fe-based pigment(s), such as iron oxides, is particularly evident in the face, in the neck and in the left breast region. The iron element is much less abundant in the hair region, which is distinguished through much higher contents in zinc. These findings suggest that the dark colors used for hair, should involve zinc white admixed with dark pigment(s) containing light elements, such as carbon black and bone black.

\section{Sky/blue background}

The MA-XRF scanning performed on Dieu n'est pas un saint also provided elemental information about the overpainted sky. As shown in Fig. 5 the fluorescence emission of the $\mathrm{Cr}, \mathrm{Zn}$ and $\mathrm{PbL}$ elements recorded all around the female figure seems related to the hidden sky and supports the use of Cr-based pigment(s), zinc white and lead white mixtures for its depiction. The identification of a chromium pigment throughout the sky is fully compliant with the results for the upper left part of $L a$ pose enchantée alias Le portrait [8]. However, the $\mathrm{Cr}$ and $\mathrm{Zn}$ elements appear more abundant in the area edging the wall. The detection of more intense $\mathrm{Cr}$ signals, originating from the paint layer beneath the dove, suddenly interrupted in the nude's right shoulder, and, the greenish blue color observed under microscope on the subsurface of the wings suggest that the right section of the sky was greener than its left counterpart.

A virtual colorization of $L a$ pose enchantée, elaborated on the basis of the MA-XRF scanning results and the examination under microscope of (accessible) subsurface 

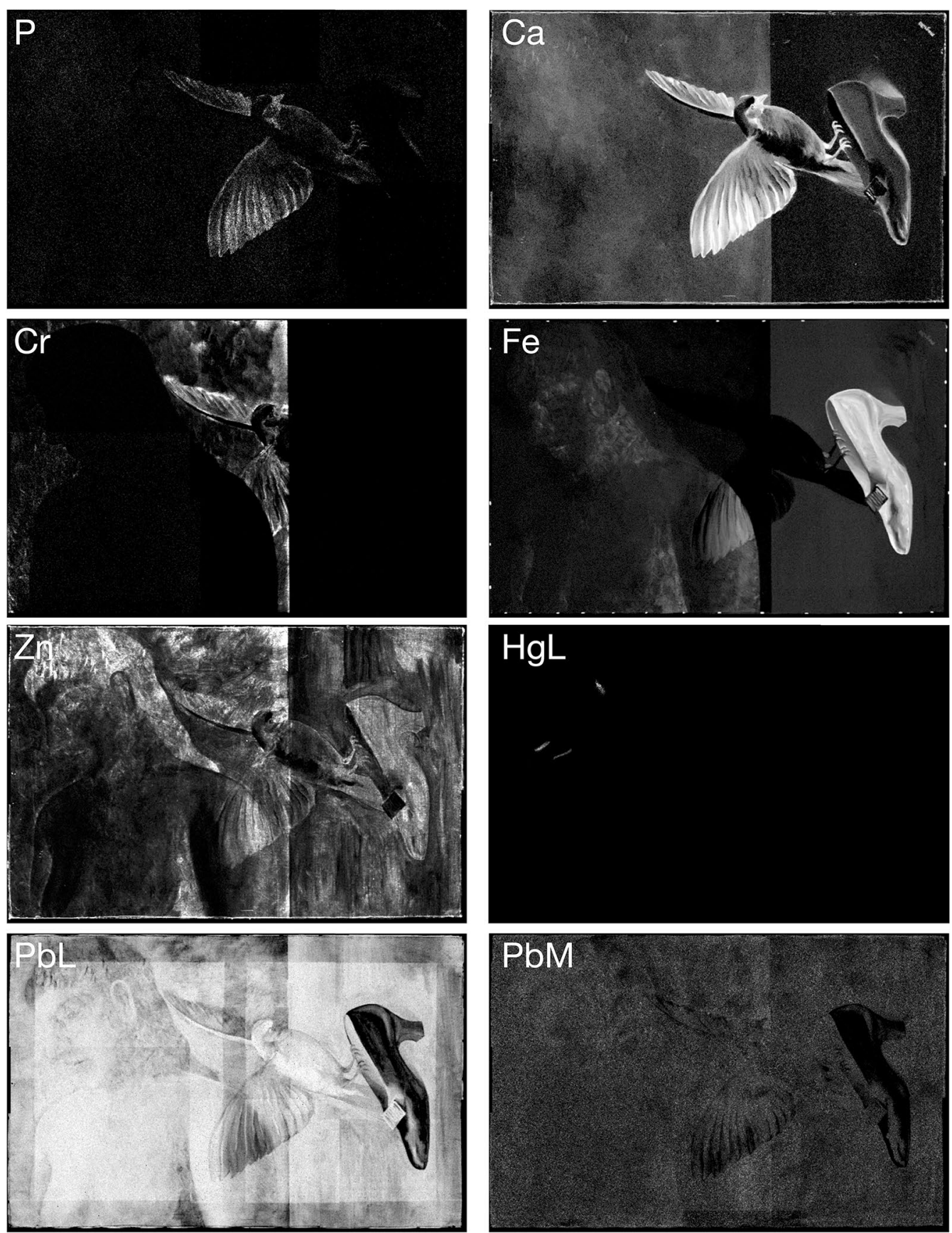

Fig. 5 MA-XRF maps showing the distribution of the $\mathrm{P}, \mathrm{Ca}, \mathrm{Cr}, \mathrm{Fe}, \mathrm{Zn}, \mathrm{Hg}$ ( $\mathrm{L}$ rays) and $\mathrm{Pb}$ ( $\mathrm{L}$ and $\mathrm{M}$ rays) elements detected all over the painting. The grey scale corresponds to the intensity of the signal of each element, black being the minimum of the signal, white, the maximum

paint layers, is proposed in Fig. 6. The As noticed above, the current blue background extends over the tacking edges, and then dissimulates the paint layers from the sky and the nude underneath. However, the examination of the blue painted edges with digital microscopy device allowed the distinction of two or three blue paint layers according the location on the edges. As shown in Fig. 7, three different blue layers are superposed on the top left corner of Dieu n'est pas un saint that corresponds to a part of the previous sky. The deepest blue layer, punctually visible under microscope and appearing lighter and greener than the upper ones, is presumed to be a tiny unscathed part of the sky from La pose enchantée. The green pigments particles observed in the $\times 200$ magnified 


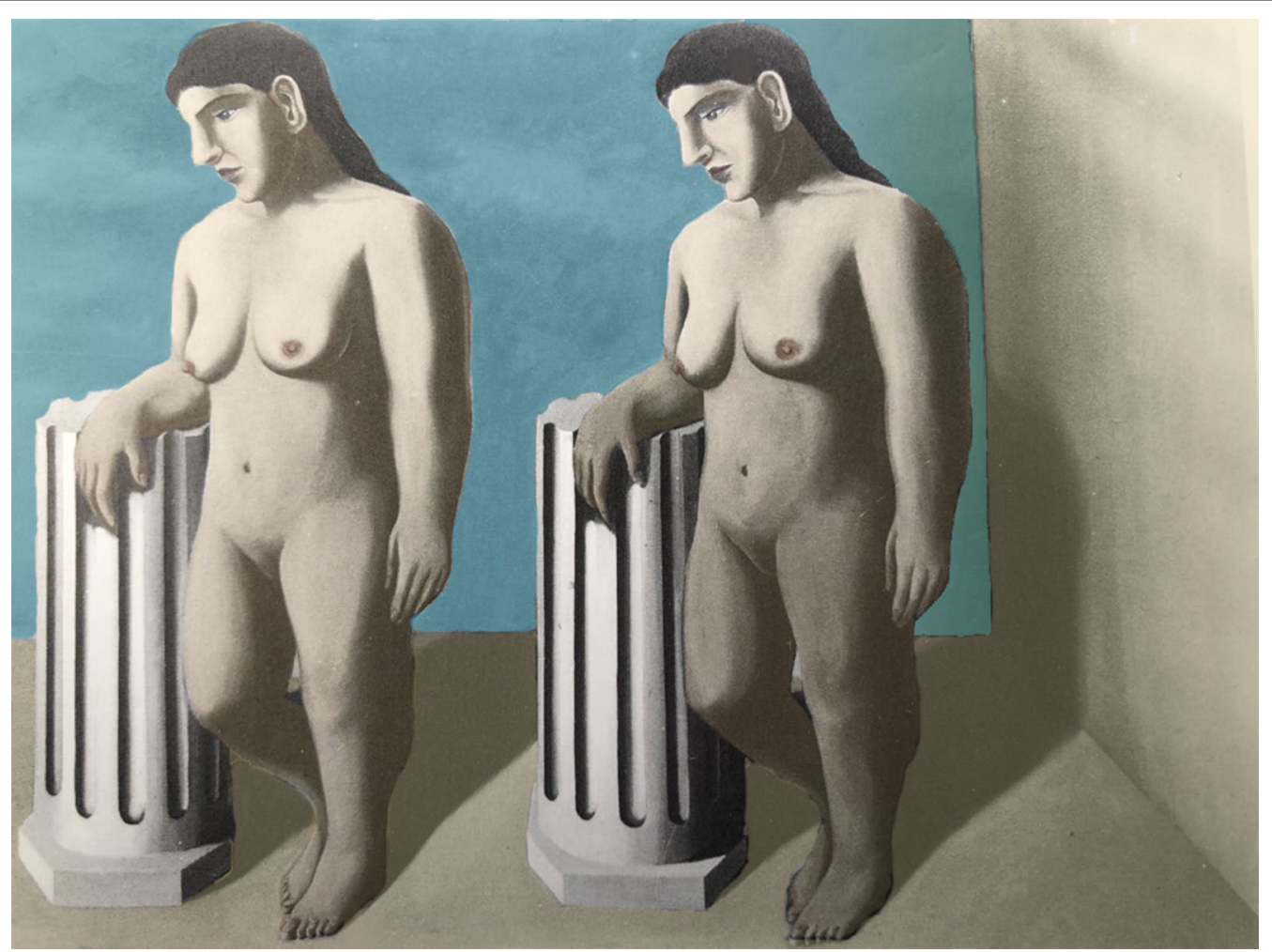

Fig. 6 Virtual colorization of the black and white photograph of La pose enchantée, reproduced in the RMCR, which has been elaborated on the basis of the MA-XRF results and the examination under microscope of the accessible subsurface paint layers

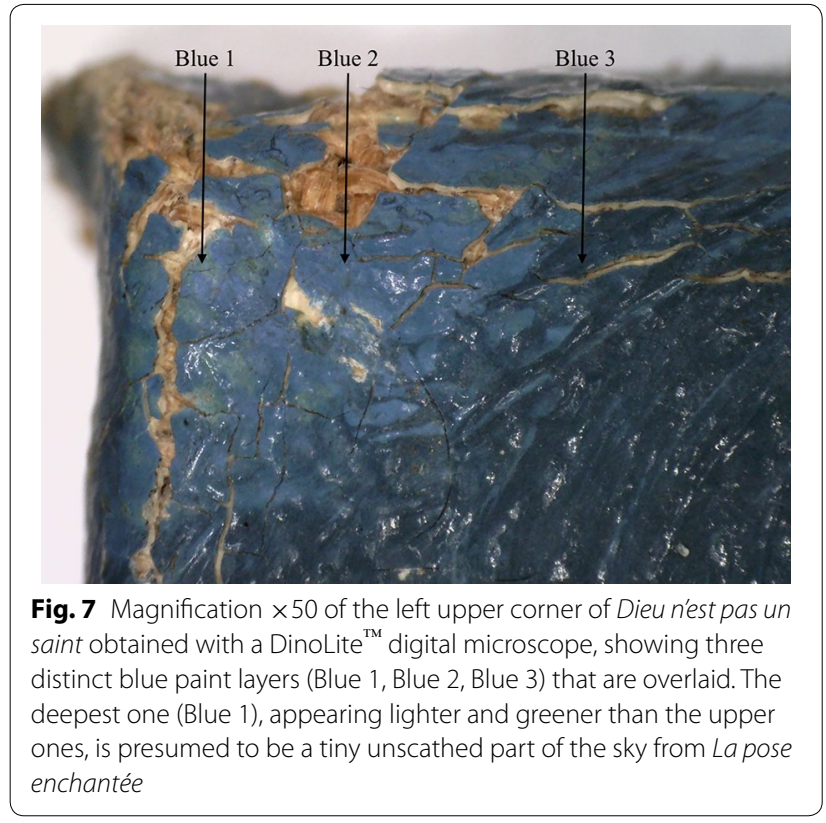

image and the detection of chromium signals through MA-XRF in the related area tend to evidence the use of a chromium green pigment to achieve the sky color shades.
This layer is also distinguishable under UV light exposure through its greenish fluorescence (see Additional file 1: Figure S1), likely resulting from its contents in zinc white. The blue layer directly applied over it exhibits a bright blue color without green shade. In comparison, the third and upper blue layer lying is much darker. The pigments responsible for the blue tones of the surface and subsurface layers remain unidentified. However, the blue color and the even distribution of calcium throughout the blue background are compatible with the presence of ultramarine [16] in the top paint layers. The detected signals of $\mathrm{P}$ (lighter than $\mathrm{Ca}$ ) and $\mathrm{PbM}$ can be considered as coming from the surface layers as well. Therefore, on the basis of the $\mathrm{Ca}, \mathrm{P}$ and $\mathrm{PbM}$ maps, shown in Fig. 5, the current blue background could be made of lead white, ultramarine and Bone black, the late one being characterized by its $\mathrm{P}$ and Ca contents [17]. The punctual Raman measurements performed on several blue sites led to the identification of lead white and bone black but did not confirm the use of ultramarine.

\section{Wall/ocher background}

In terms of composition, the ochre and blue backgrounds have in common all the elements detected by MA-XRF, 
except chromium and mercury. The even distribution of the $\mathrm{Fe}, \mathrm{PbM}, \mathrm{Ca}$ and $\mathrm{P}$ elements in the overall ochre region suggests the presence of iron oxide pigment(s), such as ochers and earths, lead white and bone black on the painting surface. Bone black and lead white were successfully identified through Raman analyses conducted on the visible ochre area. A close examination of the ocher brushstrokes surrounding the dove and the shoe pointed out that they were applied subsequently to the depiction of both features. Regarding the wall lying beneath the ocher background, the $\mathrm{Zn}$ and $\mathrm{PbL}$ distribution maps indicate subsurface layers zinc white rich, involving lead white as well. As mentioned above, the skyline, dividing the top blue and the lower ochre background, perfectly overlaps the demarcation line of the wall belonging to the former composition. The dark brown borderline partly covered by the upper ocher paint layer could then correspond to the left outline of the overpainted wall. Interestingly, the examination of the ocher region edging the skyline under microscope revealed the presence of darker grey/brown under layers. Inversely, the buff-colored underlayer partly visible on the lower edge, which fluoresces under UV light (see Additional file 1: Figure S1), supports the use of much brighter tones in the outside section of the wall. These findings tend to evidence that the hidden wall was made of different shades of brown and grey, lighter and lighter from left to right. The MA-XRF measurements conducted on a part of the lower tacking edge showed that the buff-colored under layer and the ocher top layer mostly differ through the intensity of the detected Zn signals. Indeed, the underlayer that emits more intense $\mathrm{Zn}$ signals clearly stands out from the $\mathrm{Zn}$ distribution map.

\section{Dove, shoe and signature}

Concerning the dove from the current image, the $\mathrm{Pb}, \mathrm{Ca}$ and $\mathrm{P}$ distribution maps suggest a prominent use of lead white and bone black for depicting the bird [18]. Punctual Raman analyses performed on the grey and black brushstrokes confirmed the combination of bone black and lead white. The detection of more intense $\mathrm{Zn}$ and $\mathrm{Cr}$ signals, associated to the former sky, in the dark grey and black shades of the dove can be explained by the fluorescence emission of both elements, which is less attenuated in the areas richer in bone black ( $\mathrm{Ca}$ and $\mathrm{P}$ being lighter elements than the $\mathrm{Pb}$, more abundant in the surrounding regions). In the same way, the $\mathrm{Fe}$ and $\mathrm{Zn}$ signals detected in the upper part of the left wing, partly covering the nude's shoulder can be considered as coming from the flesh tones lying beneath. The shoe seems mainly made of iron-based pigment(s) admixed with variable proportions of lead white, the white pigment being more abundant in the lightest brown shades found in the buckle and inside the shoe. The use of earth pigments could explain the concomitant presence of $\mathrm{Ca}$ and $\mathrm{Fe}$ elements found out in the shoe and in the legs of the bird. One can see that the signature stands out in the Fe and Ca maps. The abundance and the even distribution of both elements are compliant with a writing based on earth pigments.

\section{Conclusions}

The in-depth study of Dieu n'est pas un saint by means of complementary imaging and analytical methods delivered plenty of material and technical information about the last missing quarter of $L a$ pose enchantée lying underneath the visible picture. While the XRR allowed visualizing the hidden composition in detail, the MAXRF analysis made possible to characterize the pigments associated to the overpainted features, as well as those related to the current composition. These results are in good concordance and complimentary with the ones obtained on the other quarters $[8,9]$. Strips of canvas of a few centimeters wide in the middle of painting are still unaccounted for. Unlike the three quarters of $L a$ pose enchantée previously discovered, the XRR has highlighted the obvious linkage existing between the picture of Dieu n'est pas un saint and the overpainted image. Indeed, the skyline dividing the top blue and the lower ochre backgrounds exactly reproduces the borderline between the sky and the wall underneath. Also, while the sky area, including the nude, has been transformed into a uniform blue background, the wall has been changed into an even ocher background. On the basis of the MAXRF results, the nude flesh tones primarily involve lead white, zinc white and iron oxide pigment(s), the sky is rich in chromium green and zinc white, and, the wall contains large amounts of zinc white. Besides the elemental composition revealed by MA-XRF for both, the hidden and the visible picture, some pigments from the surface paint layers have been successfully identified through RS. A close observation of the painting with the naked eye and the examination of areas of interest under microscope provided further material evidences regarding the original appearance and the transformation process of the right top part of La pose enchantée. The hidden wall certainly exhibited different shades of brown and grey, lighter and lighter from left to right and the blue sky most probably displayed uneven bright greenish blue shades.

\section{Additional file}

Additional file 1: Figure S1. Photography under UV light of Dieu n'est pas un saint. @Ch. Herscovici, Belgium. 


\section{Authors' contributions}

$\mathrm{CD}, \mathrm{EH}$ and DS have realized the in situ measurements (imaging, XRF and Raman), CD, DS, FV and FL have interpreted the results of the analysis. All authors read approved the final manuscript.

\section{Author details}

${ }^{1}$ Centre Européen d'Archéométrie, UR Art, Archéologie, Patrimoine, University of Liège, Allée du 6 Août 10, Sart Tilman B15, 4000 Liege, Belgium. ${ }^{2}$ Royal Museums of Fine Arts of Belgium, Rue du Musée 9, 1000 Brussels, Belgium.

\section{Acknowledgements}

The authors sincerely thank Michel Draguet, General Director of the Musées Royaux des Beaux-Arts de Belgique/Koninklijke Musea poor Schone Kunsten van België (MRBAB/KMSKB), for his commitment that greatly assisted this research. The authors would like also to express their gratitude to Ludovic Godfrin, Modern painting collection keeper at the MRBAB/KMSKB, for his technical assistance.

\section{Competing interests}

The authors declare that they have no competing interests.

\section{Ethics approval and consent to participate}

Not applicable.

\section{Publisher's Note}

Springer Nature remains neutral with regard to jurisdictional claims in published maps and institutional affiliations.

Received: 25 February 2018 Accepted: 10 May 2018

Published online: 15 June 2018

\section{References}

1. Draguet M. Magritte. Folio biographies. Paris: Gallimard; 2014. ISBN 2070450176.

2. Gohr S. Magritte: attempting the impossible. New York: Distributed Art Publishers, Inc.; 2009. ISBN 1933045930.

3. Marcadé B. Magritte. Paris: Citadelles \& Mazenod; 2016. ISBN 2850886823.

4. Canonne X. René Magritte: the revealing image. Antwerpen: Ludion; 2017. ISBN 9491819739
5. De Corcos M. René Magritte à Francis Bacon: psychanalyse du regard. Paris: Presses Universitaires de France; 2009. ISBN 2130574262.

6. Sylvester D, Whitfield S. René Magritte—catalogue Raisonné, tome I: oil paintings 1916-1930. Houston: Menil Foundation \& Fonds Mercator; 1992. ISBN 9061532744.

7. Duffy M, Albertson C. The discovery of Magritte's The enchanted Pose. In: Inside/Out; 2013. http://www.moma.org/explore/insid e_out/2013/10/31/the-discovery-of-magrittes-the-enchanted-pose. Accessed 25 Nov 2017.

8. Vandersnickt G, Martins A, Delaney J, Janssens K, Zeibel J, Duffy M McGlinchey C, Van Driel B, Dik J. Exploring a hidden painting below the surface of René Magritte's Le portrait. Appl Spectr. 2016;70:57-67.

9. da Silva AT, Legrand S, Van der Snickt G, Featherstone R, Janssens K, Bottinelli G. XRF imaging on René Magritte's La condition humaine: insights into the artist's palette and technique and the discovery of a third quarter of La pose enchantée. Heritage. Science. 2017;5:37.

10. Strivay D, Clar M, Rakkaa S, Defeyt C. Development of a translation stage for in situ noninvasive analysis and high-resolution imaging. Appl Phys A. 2016;122(11):950. https://doi.org/10.1007/s00339-016-0476-y.

11. Hocquet FP, Calvo del Castillo H, Xicotencatl A, Bourgeois C, Oger C, Marchal A, Clar M, Strivay D. Elemental 2D imaging of paintings with a mobile EDXRF system. Anal Bioanal Chem. 2011;399(9):3109-16.

12. Hocquet FP, Garnir HP, Marchal A, Clar M, Oger C, Strivay D. A remote controlled XRF system for field analysis of cultural heritage objects. X-Ray Spectrom. 2008;37:304-8.

13. Herens E, Defeyt C, Walter P, Strivay D. Discovery of a woman portrait behind La Violoniste by Kees van Dongen through hyperspectral imaging Herit Sci. 2017:5:14.

14. Solé VA, Papillon E, Cotte M, Walter Ph, Susini J. A multiplatform code for the analysis of energy-dispersive $\mathrm{X}$-ray fluorescence spectra. Spectrochim Acta B. 2007;62(1):63-8.

15. Lauwers D, Garcia Hutado A, Tanevska V, Moens L, Bersani D, Vandenabeele $P$. Characterisation of a portable Raman spectrometer for in situ analysis of art objects. Spectrochim Acta B. 2014;118:294-301.

16. Roy A. Artists' pigments: a handbook of their history and characteristics, vol. 2. Washington: National Gallery of Art; 1993.

17. Eastaugh N, Walsh V, Chaplin T, Siddall R. Pigment compendium: a dictionary and optical microscopy of historical pigments. Abingdon: Routledge; 2008. ISBN 9780750689809.

18. Sylvester D, Whitfield S. René Magritte_catalogue Raisonné, tome II: oil paintings 1931-1948. San Francisco: Wittenborn Art Books; 1993. ISBN 9780815042938.

\section{Submit your manuscript to a SpringerOpen ${ }^{\circ}$ journal and benefit from:}

- Convenient online submission

- Rigorous peer review

- Open access: articles freely available online

- High visibility within the field

- Retaining the copyright to your article

Submit your next manuscript at $>$ springeropen.com 